\title{
Can the strategy of "mediate first" reduce collective labor disputes?-An empirical test based on province-level panel data from 1999 to 2011
}

\author{
Wenjia Zhuang
}

\section{Correspondence:}

zhuangwj3@mail.sysu.edu.cn

Center for Chinese Public

Administration Research, School of

Government, Sun Yat-sen University,

Guangzhou, China

\section{空 Springer}

\begin{abstract}
In China, the transformation of economy and the reform of the labor system since the 1980s have seen a large number of collective labor disputes, yet the scale and intensity of these disputes have been effectively controlled. A trend has been observed that those disputes are more and more individualized. Especially since the new century, the size and frequency of collective labor disputes accepted by governmental arbitration institutions gradually decreased. What factors reduced the number of collective labor disputes that were handled by formal dispute resolution channels? Based on provincial-level panel data from 1999 to 2011 and quantitative analysis, this paper finds that in the transition years, the Chinese state actively strengthened various mechanisms to mediate labor disputes, which absorbed and defused the collective struggles of workers. However, these mediations significantly reduced only the scale of the collective labor disputes rather than the frequency of their occurrence. High selectivity of mediation accounts for this phenomenon: authorities focused primarily on the prevention of large-scale disputes and neglected individual or small-scale disputes. This finding responds theoretically to the discussion of the absence of massive labor movements during China's transition and conceptually highlights the mediator role of the Chinese state, which flexibly eased the struggles of workers. Empirically, this work also discusses why the absolute number of labor disputes in the transition remained stubbornly high and why they were consistently mediated but unsolved.
\end{abstract}

Keywords: Mediation; Labor dispute; Labor protest; Repression; Labor arbitration

\section{Background}

Two trends occurred in the collective disputes accepted by labor arbitration institutions from 1993 to 2011: the scale of disputes was reduced, and, in contrast to individual disputes, the frequency of collective disputes also decreased (see Fig. 1). The scale of collective labor disputes has declined significantly since the early twenty-first century. From 1993 to 2003, the average scale of participants in collective disputes was thirty-four people, whereas between 2004 and 2011, the average was twenty-four people. ${ }^{1}$ In 2008, The Law of Labor Disputes Mediation and Arbitration (hereinafter Law of Mediation and Arbitration) adjusted the definition of collective disputes from 


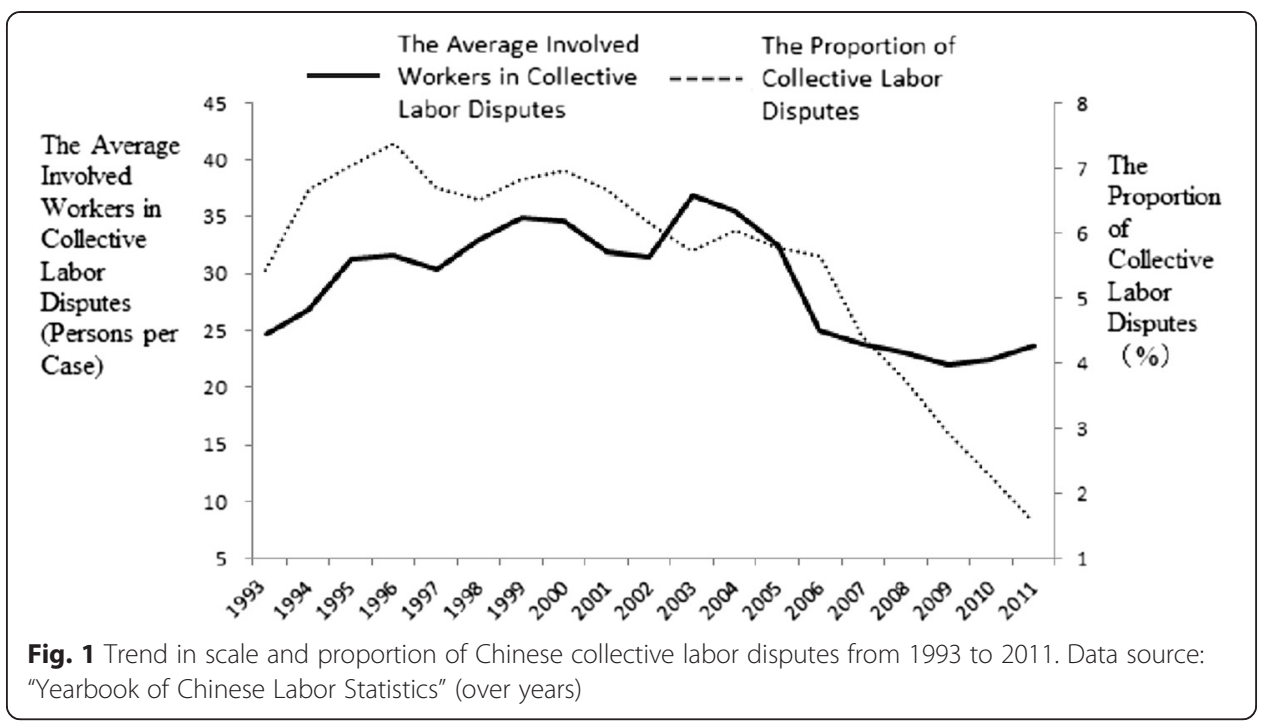

involving three or more people to more than ten people. Correspondingly, the average scale of collective labor disputes was expected to suddenly surge. However, the statistics from 2008 did not reflect any significant change, demonstrating the continuation of a decreasing scale of disputes in spite of the enactment of the Law of Mediation and Arbitration. The proportion of collective disputes accepted by arbitration institutions fell sharply, decreasing from $7.84 \%$ in 1995 to $3.16 \%$ in 2008 and continuously declining to $1.19 \%$ in $2011 .{ }^{2}$ Even taking the impact of the adjusted statistical rules from 2008 into consideration, this decline was very significant. What factors reduced the frequency and scale of collective labor disputes inside the arbitration channels?

This article argues that since the mid-1980s, the Chinese government has been actively strengthening its institutional role as a mediator and its substantive power in settling collective labor disputes, and mobilizing all mediatory agencies to continuously take the initiative to intervene, absorb, and defuse collective labor disputes. Workers' actions have gradually been atomized. On the basis of quantitative analysis of provincial-level panel data from 1999 to 2011, this study finds that mediation by arbitration institutions has significantly reduced the scale of collective labor disputes, yet failed to decrease the frequency of their occurrence. This phenomenon is due to selective intervention strategies that disregard small-scale disputes and focus only on large-scale disputes. This selection process has led to a statistical decrease of large-scale collective cases, yet an overwhelming number of small-scale disputes remains. These findings theoretically respond to the question of why no massive labor movement occurred during China's transition period, conceptually highlights the state as a mediator that diverted workers' protests with flexible strategies, and empirically addresses the reason why the absolute number of disputes stayed at a high level and were often mediated but unsolved.

\section{A review of the role of the state in labor disputes in the transition period}

In China, no other question is discussed more in the existing literature over the past 20 years than why a massive labor movement did not take place during the transition. One of the most controversial aspects is the role of the state in resolving labor conflicts. In this regard, existing research has mainly been based on four perspectives: the 
first is corporatism that focuses on the effects of economic reform and social transformation on the role and action of trade unions (Chan 1993; Chen 2003, 2004, 2009, 2010); the second is legalism, which concerns the influence on labor protection and rights protection of workers through labor legislation and the regulatory system of labor (Burell 2001; Ngok 2008; Wang 2006); the third is authoritarianism, which focuses mainly on local political authorities' repressive actions against workers' protests (Cai 2002, 2004, 2006, 2008); and the fourth is the neotraditionalism perspective that concerns the relationship between management layers and workers in state-owned enterprises in the postMao era (Lee 1999; Walder 1986). These perspectives basically cover the four images of state-society relation in the China studies mentioned by Wank (1998): the class image, the traditionalist image, the totalitarian image, and the managerialistic image. These different scenes are intertwined rather than completely separated (Howell 2006). However, according to the different approaches of research (institution-centered or agencycentered), and the differences in the definition of labor identity (class identity or citizenship), these studies can be roughly divided into four categories (Fig. 2).

The perspectives of corporatism and neotraditionalism tend to initiate the discussion of the relationship between the state and labor from the view of class identity. They therefore focus on labor protests in state-owned enterprises (hereinafter SOEs) and actions by labor unions. The former emphasizes that labor unions have some agency beyond institutional designs, while the latter stresses the path dependency of the institutional legacy from the planned economy in the reform period. In contrast, legalism and authoritarianism perspectives tend to treat the protests of Chinese workers during the transition as a rights-defending movement of citizenship rather than collective actions based on class identity. Specifically, legalism emphasizes the institutional constraints on state agents (for instance, local authorities, labor bureaucracy, and courts) and workers' actions as defined by policies, laws, and the newly developed regulatory system, whereas the authoritarianism perspective focuses on how local authorities create and deal with workers' rights protection.

However, studies based on class identity are mainly concerned with the conflicts triggered by the reform of SOEs in the initial stage of reform. The neotraditionalist perspective is reluctant to explain why the fight by workers in non-state-owned enterprises since the mid- to late 1990s was controlled, and the corporatism perspective fails to explain the absence of labor movement in foreign and private enterprises in which labor unions are weak. Moreover, the analytical perspective based on class identity may have some limitations in regard to the legally mobilized actions by workers through institutional channels

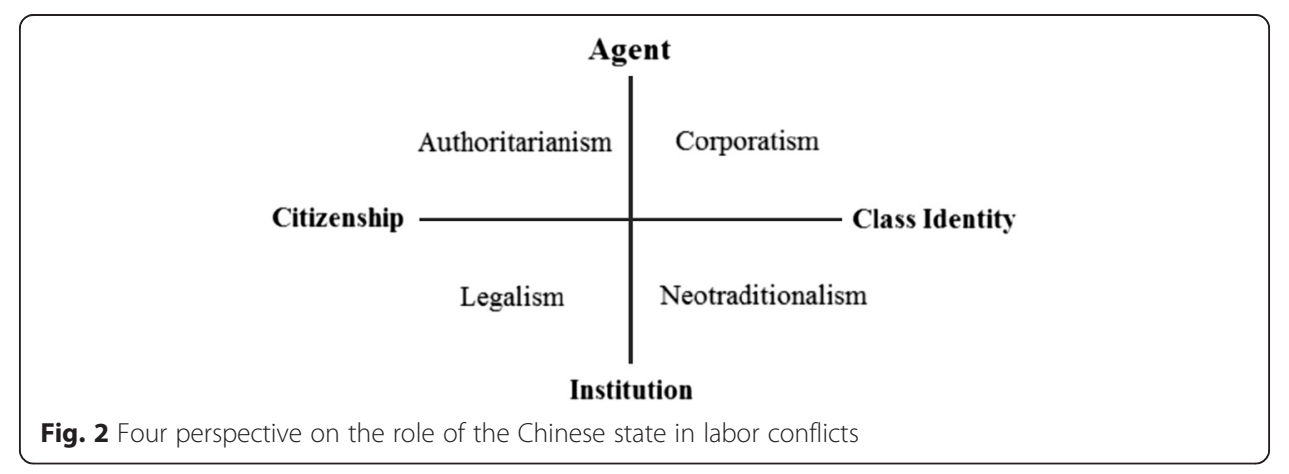


such as labor arbitration, as is discussed in this paper. As Lee $(2007,12)$ states, the largest increasing labor population during the transformation period is the rural migrants. The three most common incentives for them to protest were wage disputes, severe disciplines and violation of personal dignity on the factory floor, and compensation for work accidents; their identity in their struggle was mainly based on citizenship and being a vulnerable group, and their actions were protests against discrimination. For SOE workers, their identity in protests was primarily based on the concepts of class, citizenship, and being a vulnerable group. However, being a member of the proletariat was an identity for protest or political discourse that workers might cite during social protests, rather than a product, as claimed by Marx, generated during the process when workers were integrated into the capitalistic mode of production; it was actually a protest of desperation (Lee 2007, 12). Chan (2012) argues that the labor protests triggered by the privatization of state-owned enterprises were essentially a fight of civil rights based on social rights rather than a fight for better working conditions that emerged from a class struggle based on particular class interests. This was particularly true for laid-off workers from state-owned companies, who had quit a productive relationship and therefore could not form real class consciousness. In contrast, the collective strikes and bargaining in the coastal areas against foreign and private enterprises in recent years appeared to be more like class struggles against employers.

The state has adopted very different approaches in response to different types of labor disputes. Chen and Tang $(2013,566)$ believe that there were three types of labor conflicts emerged during China's transformation: in the early stage, the protests of workers from state-owned enterprises were based on a moral economy, mainly in pursuit of wage and social security that would maintain their living standard. These protests were in accordance with the socialist discourse and survival ethics before the reform, and mainly took the form of leapfrog petitions and sit-down protests. The authorities responded mainly by introducing special relief programs and discouraging protests. Later, more rights protection action in the non-state-owned sector was carried out in light of the concept of rights, in pursuit of legally secured wages (and wages for overtime work) and compensation for work-related injuries. Such action relied on specific laws and policies, and usually took the form of arbitration and litigation. The authorities responded mainly through (quasi-)judicial disposition and providing legal services. However, in recent years, more and more protests concerned conflicts of interests. They aimed at increasing wages and improving working conditions, were based on a sense of economic fairness, and mainly took the form of strikes. The responsive strategies of authorities changed to communicating and negotiating with protesters and employing force to break up the protesters (Chen and Tang 2013, 566).

Since this paper mainly discusses legal rights protection of workers based on civil rights rather than the strikes of industrial workers and collective negotiations, its perspective consequently focuses on the relationship between the state and workers based on citizenship. In this regard, the existing legalism perspective mainly emphasizes the path dependence of institutions and their subsequent constraints on workers. For example, Chen (2007) believes that the Chinese state actively met the rights of individual workers (contracts, wages, working conditions, benefits, and so on) through labor legislation, but did not grant workers collective rights (rights to forming organizations, strikes, collective bargaining, and so on). Lack of collective rights always led to the 
absence of individual rights. This selective empowerment was rooted in the political tradition of Leninism and the current national development strategies (Chen 2007). Similarly, Gallagher (2006) also stresses the impact of legal individualism on the individualization of collective actions and labor disputes by Chinese workers. However, these studies overestimated the impact of the static legal system on workers. Neither did they explain why, given the universal national labor policies, a huge difference existed in the collective actions of workers in different places.

Another actor-centered perspective stresses the toughness of the authoritarian state in repressing workers' protests. As defined by Tilly, repression is "any action by the other party of protest that increases the cost of collective actions by protesters" (Tilly 1978, 100). Cai (2008) states that the central government sometimes acquiesced to the suppression of protesters by local governments since it could avoid the spread of protests and the appearance of social organizations. However, in order to avoid continued repression that might tempt the masses to seek alternative political systems, the central government occasionally intervened and punished local officials who provoked incidents of rights protection so as to preserve the legitimacy of governmental rights. Moreover, the repression of labor struggles carried out by the state included rigid crackdowns such as the use of the armed forces. Oberschall (1973) conceptually distinguishes two types of repression: rigid and coercive measures, and pliable channeling strategies. Coercive measures were generally the direct use of police, army, and other armed forces, while channeling took the form of various indirect restrictions on the methods, time, and resources of protest. Earl (2003, 2006) deems that the latter also played an important role. The above perspective of authoritarianism only observes coercive repression and ignores the effect of channeling on the control of labor struggles. Based on the latter, this paper treats the mediation mechanism as a strategy of channeling repression, and explores the effect of this strategy on the handling of labor disputes.

\section{Mediation as a channeling strategy to resolve collective labor disputes}

Since 1987 when the formal system for handling labor disputes was rebuilt, a variety of mediation mechanisms has been used by authorities to resolve collective labor disputes. This flexible strategy of governance took slightly different forms in different stages of implementation, but its logic of adjustment of the regime has been consistent-it aims at maximizing the absorption and resolution of collective labor disputes, thereby preventing the uniting of collective interests, awareness, and actions of workers. The mediation mechanism for labor disputes in China between 1987 and 2012 can be divided into three general phases: from 1987 to 1992, an internal mediation model featuring mediation committees inside enterprises; from 1993 to 2007, an arbitral mediation model featuring institutes of labor arbitration; and from 2008 to 2012, a grand mediation model featuring the use of a variety of mediation power and resources integrally and strategically.

\section{(1) 1987-1992: Mediation inside enterprises}

After the completion of the socialist transformation in 1956, labor disputes were regarded as contradictions among the people and always disposed of by the petition channel. In January 1985 when the state council issued the Announcement on the Issue 
of Wage Reform of State-owned Enterprises to implement the wage distribution system that linked payment to individual performance, the old system was already unable to accommodate the surge of grievances and dissatisfaction among the workers. According to incomplete statistics, in 1988, the number of stoppages and strikes due to labor disputes was three times more than that of 1987 and eight times more than that of 1986. In Liaoning Province, between January and July alone, 276 incidents of business leaders being violently threatened or beaten took place, resulting in three deaths, 31 serious injuries, and 120 minor injuries (Yearbook of Chinese Labor Department 1990, 324-27). The fierce conflicts triggered by the wage reform caused the central government to attach great importance to the reconstruction of the system for resolving labor disputes. On April 18, 1986, the Central Committee of the Communist Party of China (CPC) and the State Council enacted the Announcement of Seriously Implementing Several Provisions on Labor System Reform, and particularly pointed out that "the reform of the labor system is related to the vital interests of the masses, involving multiple aspects, requiring strong policies as backup, and is difficult to be implemented...in the process of implementing these provisions. We should pay great attention to letters and petitions from people and the disposal issues of labor disputes" (Central Committee of the Communist Party of China, and State Council 1986). On July 12 of the same year, the State Council published the Notice of Issuing Four Provisions to Reform the Labor System, mentioning for the first time the reconstruction of arbitral institutes for labor disputes. On July 31, 1987, the State Council issued the Interim Provisions for the Disposal of Labor Disputes in State-owned Enterprises (hereinafter interim provisions), marking the resumption of an arbitral and litigation system that had been suspended for three decades. The main goal of rebuilding this system was to control the collective struggles of workers resulted from the reform of state-owned enterprises. In accordance with the interim provisions, the disposal system for labor disputes formed a mode of "one mediation, one arbitration, and two lawsuits." Labor disputes in stateowned enterprises would first be mediated by mediation committees inside the enterprises. If this failed, workers could apply for labor arbitration before they refused to accept arbitral results and sued in the people's courts.

In fact, before 1993, the vast majority of labor disputes were resolved within enterprises and did not progress to formal procedures (see Table 1). In this period, the state quickly established a large number of mediation committees inside the state-owned and collective enterprises based on the existing networks of trade unions inside them. According to the statistics of 22 provinces and autonomous regions, there were 57,786 mediation committees by the end of 1989 (Yearbook of Chinese Labor Department 1990, 324-27). By 1992, state-owned enterprises in all regions had as many as 108,460 mediation committees, which approached a coverage rate of $60 \%$ (Office of Policy

Table 1 Mediation results by enterprise mediation committees, 1991 and 1992

\begin{tabular}{lll}
\hline Year & 1991 & 1992 \\
\hline Cases accepted by enterprise mediation committees & 94,398 & 84,286 \\
Cases successfully mediated by enterprise mediation committees & 63,539 & 58,576 \\
Mediation rate by enterprise mediation committees & $67.31 \%$ & $69.50 \%$ \\
Cases formally accepted by labor arbitration institutions & 7633 & 8150 \\
\hline
\end{tabular}

Data sources: Yearbook of Chinese Labor Unions Statistics, Yearbook of Chinese Labor Statistics, Chinese Yearbook of Labor (over years) 
Research of All-China Federation of Trade Unions [ACFTU] 1994, 334). These organizations were able to resolve a large number of labor disputes because many controversies lacked the legal basis for arbitration or litigation (Pereenbom 2009). Therefore, many labor disputes, even if sent to arbitral institutes, could basically be settled through multiple mediations (see Table 2).

By the end of 1992, of the approximately 1 million cases of labor disputes handled by various types of settlement institutes around the country, more than $70 \%$ were settled by mediation committees in enterprises, while $25 \%$ were mediated outside arbitral institutes before being filed. Only about 50,000 dispute cases were formally accepted by arbitral institutes; of these, only about $10 \%$ were arbitrated, while the other $90 \%$ were settled either by mediation or withdrawal by prosecutors after mediation. ${ }^{3}$ There are three reasons that mediation became the main way to resolve disputes. First, since national legislation in the field of labor had not been well developed in this period, arbitrators lacked criteria and legal basis when handling these cases; they could only handle cases through mediation (Yearbook of Chinese Labor Department 1990, 324-27). Second, labor arbitral institutes across the country were at the initial stage of reconstruction; their personnel were inadequately trained and often relied on local mediation to defuse escalating cases (Yearbook of Chinese Labor Department 1990, 211-14). Finally, in addition to the inability of the legal system and weak administrative capacity, mediation was also the state's principal strategy to maximally control social conflicts resulting from intensive transformation. The reform of state-own enterprises brought about collective rather than individual conflicts, which often evolved into slowdowns, stoppages, strikes, and violence (Cai 2006; Chen 2000). Through mediation, the state could fully intervene into collective conflicts, handle them through institutionalized channels, disperse the solidarity of workers, and minimize the social conflicts triggered by institutional changes.

\section{(2) 1993-2007: Mediation by labor arbitration institutions}

By the early 1990s, workplace mediation, as the first line of defense, began to fail, for three main reasons: first, enterprise mediation committees mainly relied on trade unions to function. Thus, only in medium or large enterprises in which the congresses

Table 2 Settlement by labor dispute arbitration institutions, 1987 to 1992

\begin{tabular}{llllll}
\hline Year & $1986.10-1987.8$ & $1988-1989$ & 1990 & 1991 & 1992 \\
\hline Extra-arbitral mediation & NA & 5546 & NA & NA & 15,000 \\
Formally accepted & 2679 & 19,453 & 9619 & 7633 & 8150 \\
Settled & 2079 & 21,473 & 9395 & 7521 & 7861 \\
Including: mediated during arbitration & 1930 & 12,946 & 5720 & 4682 & 4712 \\
$\quad$ & 125 & 1789 & 932 & 1027 & 1178 \\
$\quad$ Arbitrated & 24 & 6738 & 2743 & 1812 & 1971 \\
$\quad$ Settled by other measures & $6.01 \%$ & $8.33 \%$ & $9.92 \%$ & $13.66 \%$ & $14.99 \%$ \\
$\quad$ Arbitration rate & $92.83 \%$ & $60.29 \%$ & $60.88 \%$ & $62.25 \%$ & $59.94 \%$ \\
$\quad$ Mediation rate & 10 & 441 & 218 & 235 & 223 \\
Appeal to court after arbitral procedure & 8.00 & 24.65 & 23.39 & 22.88 & 18.93 \\
\hline
\end{tabular}

Data sources: Chinese Yearbook of Labor (over years) and Chinese Labour Net (http://www.labournet.com.cn) The item of "settled by other measures" refers mainly to reconciled and withdrawn cases 
of workers and the structures of trade unions were well developed could mediation committees play a truly effective role. However, neither trade unions nor mediation committees inside collective enterprises, private enterprises, and foreign-funded enterprises were well established. Second, trade unions in enterprises were not economically independent from the managerial layers of corporations. It was difficult for unions to adopt impartial dispositions. Consequently, workers often refused to accept the mediation offered by mediation committees or trade unions within enterprises. Third, prior to the 1990s, the vast majority of labor disputes were triggered by the reform of stateowned enterprises, while after the 1990s, more and more labor disputes occurred outside state-owned enterprises (Gallagher 2006). Especially in foreign-funded and private enterprises, labor conflicts were intensified, often leading to collective stoppages, slowdowns, and strikes (Chinese Labor Net 2009). In April 1993, eight cases of consecutive strikes, work stoppages, and petitions occurred in Fujian Province. In May, the leaders of the central government learned about this from the Bulletin of the Ministry of Public Safety and immediately sent instructions and urged the relevant departments to study countermeasures. In June, the central government held a national symposium on the issue of collective negotiations and strikes. Meanwhile, the Ministry of Labor urgently issued the Notice of the Prevention and Treatment of Collective Petitions and Strikes by Workers, which urged local departments of labor to educate workers in a timely manner, to intervene in, channel, and quell workers' protests, and report statistical information on collective petitions and strikes. In July, the State Council promulgated the "Regulation on Handling Labor Disputes in Enterprises" (hereinafter Regularization on Disputes). It broadened the scope of application from inside state-owned enterprises only to labor disputes in all types of enterprises. Moreover, the Regularization on Disputes was also applicable to disputes between workers and state organs, institutions, and social organizations, as well as between individual businesses and workers or apprentices.

In addition, the new regulation also explicitly set "focusing on mediation and timely treatment" as the first principle of the resolution of labor disputes. Shortly after the introduction of the Regularization on Disputes, the leaders of the Ministry of Labor stressed that workers in collective labor disputes should apply for mediation. If they turned directly to strikes or lockouts without applying for mediation, they would be penalized according to security regulations. Moreover, during the application of mediation and the process of conciliation, workers could not turn to strikes or other acts (Yearbook of Chinese Labor Department 1995, 158-62). Under these circumstances, labor arbitration became the core of the new system. In order to avoid the occurrence of large-scale collective actions by workers, the Ministry of Labor required local institutions of labor arbitration to promptly resolve disputes and avoid protracted cases that could lead to trouble, especially in dealing with sudden cases triggered by collective disputes. The fastest way to close cases was to make mediation a priority. At the time, the Ministry of Labor explicitly assigned tasks, urging the proportion of mediation and withdrawal to increase from $82 \%$ to more than $90 \%$ at the end of 1995, and the clearance rate rose from $73 \%$ to at least $85 \%$ (Yearbook of Chinese Labor Department 1995, 151-57).

Pushed by the governments, the proportion of mediated cases among all cases admitted by labor arbitral institutes remained stubbornly high during this period (see Fig. 3). Prior to 1996, the proportion of arbitral or extra-arbitral mediated cases exceeded 


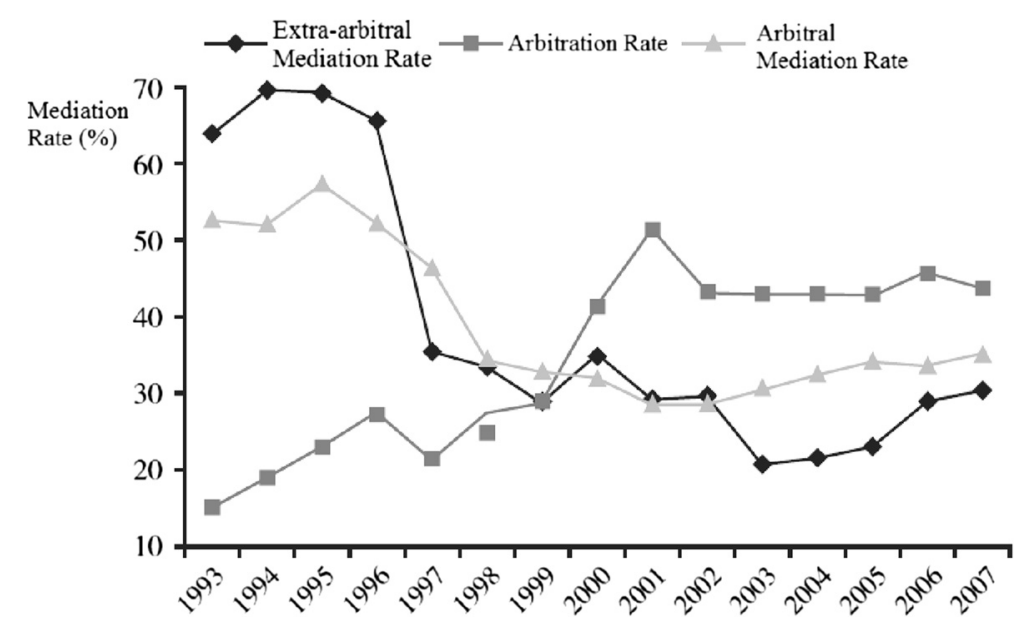

Fig. 3 Settlements by Chinese labor arbitration institutions, 1993 to 2007. Data source: Yearbook of Chinese Labor Statistics (over years)

$50 \%$; litigants also withdrew many cases after mediation. The actual proportion of cases that were directly ruled by the labor departments and closed was less than $30 \%$. At the same time, in order to strengthen the capacity of labor arbitral institutes to intervene into frequently occurring labor disputes, the Ministry of Labor issued the Outlined Tutorial of Handling Labor Disputes (January 3, 1995), the Appointment and Management Guidelines of Labor Arbitrators (March 22, 1995), the Notice of Further Improving the Framework of Tripartism in Labor Disputes (March 18, 1996), the Notice of Determined Pilot Areas for Improving the Settlement System of Labor Disputes (July 25, 1996), and a series of other documents. A nationwide training program for labor arbitrators and mediators was also launched (Yearbook of Chinese Labor Department 1998, 190). The construction of a top-down promoted organization expanded the coverage of labor arbitration institutions and enriched the resources of institutions. The situation in which the authorities were trapped in bureaucratically filed arbitrations, a situation that was originally due to the lack of resources, was greatly eased. Meanwhile, the standardization of the arbitration proceedings also helped absorb the disputes that did not originally meet the conditions of admission. In 1997, the proportion of cases extra-arbitrarily mediated was greatly reduced, while the proportion of arbitrated cases increased significantly. However, after 2000, the proportion of cases mediated and conciliated outside or inside began to gradually rebound before stabilizing. It is worth noting that from 1993 to 2007, most annual proportions of arbitration were under $50 \%$, except for 2001 when it reached the peak of $51 \%$.

\section{(C) 2008-2012: Grand mediation and classified mediation}

Mediation by labor department soon encountered a bottleneck. At the end of 1995, China had 11,292 part-time and full-time arbitrators of labor disputes (Yearbook of Chinese Labor Department 1997, 135); in 2006, the number of full-time arbitrators was about 9800, with 14,000 part-time (Ministry of Labor and Social Security, 2008). In stark contrast to the slow expansion of the number of arbitrators, the number of labor disputes reaching arbitral institutions increased by nearly 15 times (including cases 
mediated outside and formally admitted) from 1993 to 2007, rising from 34,159 to 502,084. ${ }^{4}$ Heavy workloads prolonged the already-cumbersome and complex arbitration proceedings. In provinces with severe labor conflicts such as Guangdong, completing a labor dispute case through the process of "one mediation, one arbitration, and two lawsuits" required nearly 1 year even without any extension, and could expand to more than 30 months if any extension occurred. The limited capacity of arbitral institutes drove a large number of workers to take the extreme action of protesting outside arbitral tribunals during the long arbitral processes. Leapfrog petitions, highway containment, looting companies' property, and destruction of equipment emerged as constant actions (Li 2008). Especially in 2005, when the number of large-scaled collective incidents triggered by labor problems increased significantly, the leadership of the Ministry of Labour began to realize that labor disputes had evolved from an issue with impacts on the economic order into a major issue that challenged the social order and triggered social instability (Yearbook of Chinese Labor Department 2007, 90-97).

In this regard, on October 11, 2006, the Sixth Plenary Session of the Sixteenth CPC Central Committee (CPCCC) passed the Decisions on Several Major Issues about Building a Socialist Harmonious Society, clearly indicating its intent to "build a government-led mechanism to safeguard people's rights and interests, achieve an organic combination of people's mediation, administrative mediation and judicial mediation, comprehensively use strategies of law, policy, finance, administration, etc. and other means of education, consultation, counseling, etc. to resolve the grassroots-level contradictions and at the initial stage". This directive not only claimed to strengthen the role of the Communist Party in the mechanism of rights protection, but also mobilized more administrative organizations and resources for the mediation of social conflicts. The leadership of labor departments interpreted the decision by the central government as a new governing approach, which was "prevent first, grassroots first, and mediate first" (see Tian 2008). This was soon integrated into a new round of labor legislation movements in 2007. In 2007, while introducing the Labor Contract Law and other legal entities, the central government also released a renewed Law of Mediation and Arbitration on December 29, 2007, and enacted it on May 1, 2008. The biggest change in this revised version was that it enhanced the government's role as a mediator in the labor disputes. The original framework of "one mediation, one arbitration, and two lawsuits" was changed to "three mediations, one arbitration, and two lawsuits." In addition to the mediation committees for labor disputes in businesses, ${ }^{5}$ mediation organizations among grassroots and organizations that mediated disputes in towns and street offices were also allowed to mediate labor disputes. The purpose of this was to directly involve governmental power into grassroots-level labor disputes. ${ }^{6}$

It is noteworthy that during this period, the state more strategically mediated labor disputes. On October 30, 2009, the Ministry of Human Resources and Social Security and other departments jointly issued the Opinion on Strengthening the Mediation of Labor Disputes, which preliminarily outlined the strategy of classified mediation. According to this opinion, mediation committees would mainly target large- and medium-sized enterprises with relatively well-developed unions; the focus of labor and social security service centers (stations) of towns and streets would lie mainly on mediating disputes from individuals and private enterprises; in dispute-prone areas and villages and communities with many businesses, justice centers and people's mediation 
committees that were originally designed to resolve disputes in the community would also strengthen their mediation function for labor disputes. In accordance with this strategy, the central labor department proposed the goal that about $50 \%$ of simple and small cases would be settled by mediation within enterprises, towns, and street offices in 3 to 5 years (Yearbook of Chinese Human Resources and Social Security Department 2010, 769). Since many new mediators were beyond the scope of the labor administration system, in April 2010, the office of the central committee of comprehensive management of social security issued the Opinion on Effective Performance of Comprehensive Investigation and Mediation of Disputes, which proposed the implementation of "grand mediation" across the country, resolving social conflicts through integrating power and resources from all institutes related to mediation (Central Committee of Comprehensive Management of Social Security, 2010). In April 2011, this proposal gained support from the other 15 ministries of the central government. They jointly issued the Guidance on Further Promoting the Mediation of Conflicts and Disputes. In August of the same year, in the National Conference on Labor Relationships the leaders of the central government again mobilized all ministries to integrate resources and strengthen cooperation to prevent and deal with significant labor disputes and incidents of the masses (Ministry of Human Resources and Social Security 2012a).

Statistically speaking, the central government's prevent first, grassroots first, and mediate first approach was well executed. In 2010, various types of labor dispute agencies accepted 1,287,400 cases, of which $6 \%$ were handled by mediation committees within enterprises; $6 \%$ by community, neighborhood, and villager committees; $17 \%$ by town and street offices; and more than $5 \%$ by district-level and county-level mediation agencies. Altogether, these agencies mediated more than $34 \%$ of total disputes (China Labor Net 2011). By 2011, among the 1,315,000 labor disputes admitted by various types of dispute mediation agencies across the country, mediation organizations had taken $50 \%$ (Ministry of Human Resources and Social Security 2012b). In 2012, mediation accounted for more than $63.06 \%$ of the resolution of 1,332,000 disputes (Chinese Labor Net 2013).

In summary, the variation of the mediator's role and function at different stages from 1987 to 2012, the basic goal that the mediation mechanism was to be used to absorb and diffuse collective labor disputes, remained unchanged (see Table 3). The state continued to consolidate its institutional role as a mediator through legislation and also through a variety of top-down political mobilization policies to strengthen its substantive mediatory capacity. Unions, the labor bureaucracy, courts, towns, street offices, and other agencies were mobilized to guard against frequent collective protests by workers. Through active and proactive intervention and persistent mediation, the state prevented workers' collective struggles from presenting a challenge to the economic, social, and even political order.

\section{Hypotheses and operationalization}

Data from 1992 to 2011 demonstrate that the labor disputes arbitrated by arbitral institutes were only the tip of the iceberg compared to all admitted cases. The principle of "mediate first" was prioritized by arbitral institutes of labor disputes in the process of filing and hearing cases in order to prevent collective actions by workers. As a consequence, the majority of the cases were mediated inside or outside the arbitral institutes 
Table 3 Transformation of the labor dispute mediation system from 1987 to 2012

\begin{tabular}{llll}
\hline Period & 1987-1992 & 1993-2007 & 2008-2012 \\
\hline Background & SOE reform & $\begin{array}{l}\text { Expansion of non-state } \\
\text { economy }\end{array}$ & Social instability \\
$\begin{array}{l}\text { Political } \\
\text { goal }\end{array}$ & $\begin{array}{l}\text { Absorbing labor petitions triggered by } \\
\text { the reform of SOE and labor policy } \\
\text { regime }\end{array}$ & $\begin{array}{l}\text { Containing labor disputes } \\
\text { in non-state areas }\end{array}$ & $\begin{array}{l}\text { Maintaining a harmonious } \\
\text { society }\end{array}$ \\
$\begin{array}{l}\text { Formal } \\
\text { institutions }\end{array}$ & $\begin{array}{l}\text { Mediate first, arbitrate later, adjudicate } \\
\text { last }\end{array}$ & $\begin{array}{l}\text { One mediation, one } \\
\text { arbitration, and two } \\
\text { lawsuits }\end{array}$ & $\begin{array}{l}\text { Triple mediations, one } \\
\text { arbitration, and two } \\
\text { lawsuits }\end{array}$ \\
$\begin{array}{lll}\text { Legal basis } \\
\text { Provisional regulation on handling } \\
\text { labor disputes in state-owned enter- } \\
\text { prises (1987) }\end{array}$ & $\begin{array}{l}\text { Regulation on handling } \\
\text { labor disputes in } \\
\text { enterprises (1993) }\end{array}$ & $\begin{array}{l}\text { Law on mediation and } \\
\text { arbitration of labor } \\
\text { disputes (2008) }\end{array}$ \\
$\begin{array}{ll}\text { Mediatory } \\
\text { mechanism }\end{array}$ & $\begin{array}{l}\text { Mediation by enterprise mediation } \\
\text { committees }\end{array}$ & $\begin{array}{l}\text { Mediation by labor } \\
\text { arbitration institutions }\end{array}$ & $\begin{array}{l}\text { Classified mediation and } \\
\text { grand mediation }\end{array}$ \\
\hline
\end{tabular}

before being submitted to an arbitral decision (see Fig. 4). As mentioned above, this pre-mediation mechanism may have reduced the scale and frequency of collective labor disputes admitted by arbitral institutes. ${ }^{7}$ In order to test these causal-effect relationships, this work constructs the following hypotheses:

Hypothesis one: Mediation has reduced the scale of labor disputes admitted by arbitral institutions.

Hypothesis two: Mediation has reduced the frequency of labor disputes admitted by arbitral institutions.

First of all, in the aspect of operationalization, the selection of dependent variables needs to be explained. The scale of labor disputes is calculated as the ratio of total number of workers involved in labor disputes to the number of collective disputes admitted by arbitral institutes of labor disputes across the country. The frequency of disputes can be measured as the proportion of admitted collective disputes in total labor disputes. In regard to the explanatory variable, the overall performance of mediation is measured by adding up the cases mediated before and after they were admitted by arbitral institutes (see Eq. 1).

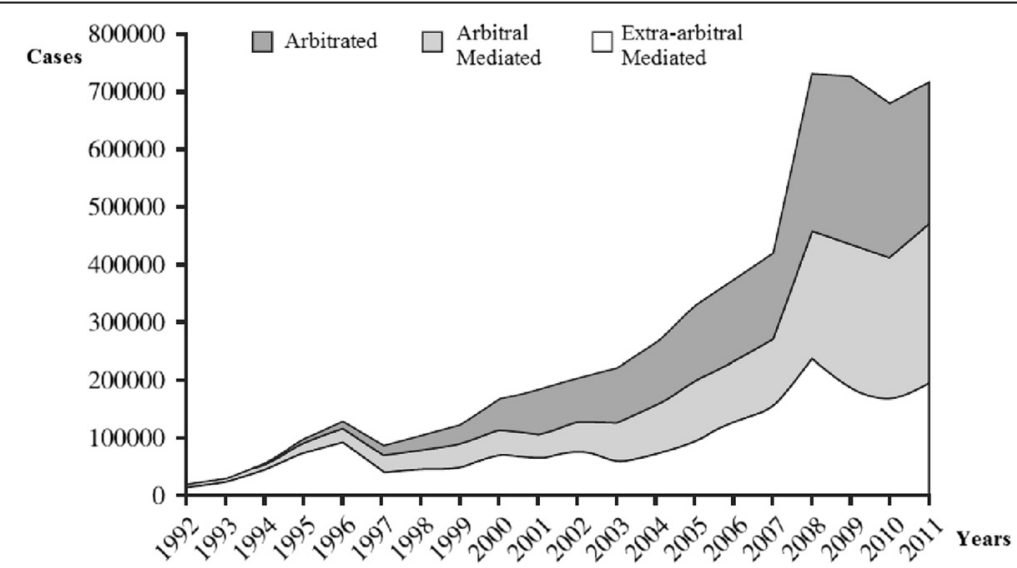

Fig. 4 Tendency of settlement by labor arbitration institutions, 1992 to 2011. Data source: Yearbook of Chinese Labor Statistics (over years) 
The mediation capacity of labor arbitral institutions
$=\frac{\text { cases settled by arbitral and extra arbitral mediation }}{\text { cases settled by extra arbitral mediation }+ \text { admitted cases }+ \text { unfinished cases from last period }}$

For control variables, exit behaviors of workers and the responses by governments deserve most consideration. Their decrease in admitted number of cases by arbitral institutes may be due to the decrease in willingness to apply for arbitral remedies but instead turn to street protests that could prompt an increased effort of mediation by local governments. This can be converted to a problem of an omitted variable, which can be overcome by controlling the proportion of complaints about the labor arbitration system (number of cases in which workers applied for labor arbitration divided by the number of the employed urban population; the unit is incidents per 10,000). Another possible omitted variable is the type of dispute. Actions for rights protection related to wages and payment for overtime work often trigger large-scale collective labor movements, whereas issues such as social insurance and welfare benefits often cause small-scale disputes. The nature of disputes also influences the level of difficulty for mediators in dealing with them. This article thus controls the different types of labor disputes by calculating the ratio of the number of labor disputes on social welfare to the number of labor disputes on payment.

The second control is the heavy-handed repression by local governments. Supervised by local committees for politics and law, the local departments of public safety, procuratorates, and courts were mobilized to control various forms of instability, including workers' rights protection that could lead to collective incidents. The abundance of resources that these local committees can mobilize determined the scale and frequency of workers' collective struggle, and could also become a bargaining chip between local governments and the two sides of employers and employees. This article measures the index of arbitrary resources that could be mobilized by local governments in terms of the expenditures of local political and legal systems averaged by the number of regular local residents (unit: yuan per person) to control the impact of repression by local governments.

In addition, the impact of grassroots-level trade unions and mediation committees of enterprises is also an important factor to be controlled. From the early 1980s, in order to avoid massive labor struggles triggered by the reform of the labor system, the state began to actively promote preemptive actions by trade unions and actively intervene into labor disputes. This strategy of corporatism effectively prevented the cohesion of interests of the working class (Chan 1993). Grassroots-level trade unions directly intervened into mediation by developing mediation committees based on their established networks. To some extent, the regular operation of mediation committees also played a preventive role in the collective actions of workers. This article thus measures the coverage of mediation committees by the number of mediation committees inside enterprises averaged by employed urban population (unit: number per 10,000 people). ${ }^{8}$

Finally, this work controls local economic conditions in the model-indices of local economic development and foreign economic dependence-that are respectively measured as per capita GDP (unit: yuan/person) and the ratio of direct foreign investment to GDP. In addition, the paper also controls the size of the urban labor population (number of urban employees; unit: 10,000), marketization of labor (proportion of employees from 
non-state-owned and non-collective enterprises in all urban employees), proportion of employees in secondary and tertiary industries, structural factors of the labor market such as the unemployment rate. Also, in order to rule out the influence of certain social and demographic structural factors, this work also indirectly controls the scale of migrants by calculating the ratio of the regular population to the household-registered population.

All data used in this article was drawn from the Yearbook of Chinese Labor Statistics and other official publications, spanning from 1999 to $2011 .{ }^{9}$ It covers 31 provinces, municipalities, and autonomous regions. Table 4 lists the basic analysis for all those above variables. Per capita GDP and per capita political and legal expenditure were adjusted to real currency based on the price index of 2000. In the model, all variables with skewed distributions were converted through natural logarithm to approximate normality.

\section{Methods}

In order to control the fixed effect of provinces and years, ${ }^{10}$ this work adopts the method of least squares with dummy variable (LSDV). Provinces and years are converted to a series of dummy variables in the model. Meanwhile, to avoid spurious regression caused by the time variable, this article includes time trend in the model as well. The regression model is expressed by the following formula:

$$
y_{i t}=\alpha+\beta x_{i t}+\theta_{k} Z_{i t}+\mu_{i}+\gamma_{t}+\varepsilon_{i t}, i=1,2 \ldots 31, t=1999,2000, \ldots, 2011
$$

In the equation above, $y_{i t}$ is the dependent variable; $x_{i t}$ is the explanatory variable; $Z_{i t}$ is a series of control variables; $\mu_{i}$ is the province-level fixed effects; $\gamma_{t}$ is the fixed effect of time; and $\varepsilon_{i t}$ is other factors that might be effective but are not identified by in mode, which is assumed to be random. The subscript $i$ represents 31 provinces, municipalities, and autonomous regions; $t$ represents the 13 years from 1999 to 2011; and $k$ is the number of control variables. To overcome the effects of heteroscedasticity, this work uses Huber-White robust standard errors.

Table 4 List of variables

\begin{tabular}{|c|c|c|c|c|c|}
\hline Variables & Obs & Mean & Std & Min & Max \\
\hline $\begin{array}{l}\text { Average involved workers per collective dispute case } \\
\text { accepted by arbitration institution (Ln) }\end{array}$ & 371 & 3.15 & 0.75 & 0.56 & 5.62 \\
\hline $\begin{array}{l}\text { Proportion of collective dispute cases accepted by } \\
\text { arbitration institution (Ln) }\end{array}$ & 371 & -3.24 & 0.97 & -6.35 & -0.25 \\
\hline Mediatory capacity of labor arbitration institutions & 302 & 0.49 & 0.14 & 0.15 & 0.88 \\
\hline Appeal rate of labor arbitration by workers (Ln) & 366 & 2.26 & 1.34 & -2.81 & 6.14 \\
\hline Ratio of social-security disputes to payment disputes (Ln) & 355 & 0.02 & 0.91 & -4.80 & 2.18 \\
\hline Expenditure on political and legal affairs per capita $(L n)$ & 355 & 4.99 & 0.74 & 2.83 & 7.19 \\
\hline Coverage of enterprise mediation committees & 371 & 13.85 & 11.26 & 0.18 & 6.04 \\
\hline GDP per capita (Ln) & 372 & 9.52 & 0.67 & 7.88 & 11.10 \\
\hline FDI dependency & 372 & 0.03 & 0.02 & 0.00 & 0.10 \\
\hline Scale of urban labor & 372 & 61.33 & 426.16 & 22.56 & 2601.89 \\
\hline Marketization of labor & 372 & 0.54 & 0.15 & 0.21 & 0.86 \\
\hline $\begin{array}{l}\text { Ratio of employees in secondary industries to those in } \\
\text { tertiary industries }\end{array}$ & 371 & 0.70 & 0.26 & 0.26 & 1.47 \\
\hline Unemployment rate & 371 & 3.71 & 0.70 & 0.80 & 6.50 \\
\hline Ratio of resident population to registered population & 372 & 1.03 & 0.12 & 0.82 & 1.65 \\
\hline
\end{tabular}




\section{Results and discussion}

As the analysis show (Table 5), the mediation by labor arbitration institutions has reduced the scale of collective labor disputes that they have admitted. In model 1 , the regression coefficient of the mediation capacity of labor arbitral institutes toward average scale of admitted labor disputes (natural logarithm) is -0.923 at the 0.05 significance level. This means that arbitral institutes' long-standing strategy of mediate first played a role in channeling workers' conflicts regarding rights protection. It effectively reduced the scale of collective labor disputes that they admitted. A variety of mediation mechanisms before arbitration functioned well to differentiate the cohesion of workers, gradually causing workers in institutionalized relief channels to act individually.

On the other hand, mediation did not reduce the frequency of occurrence of collective disputes. In model 2, the mediation capacity of arbitral institutes does not pass the significance test, which might be caused by arbitral institutes' selective intervention. Under pressure to maintain social stability, governments mainly focus on the incidents of the masses related to large-scale collective labor disputes rather than cases of relatively small scale or by individuals that were not mediated with priority. As stipulated in the Law of Mediation and Arbitration, cases of more than ten people are considered collective disputes. However, for arbitral institutes, collective cases involving 11 people are not very different from individual cases involving nine people. Under the circumstances of a high workload but limited number of arbitrators, only cases of rights protection involving large numbers of workers were likely to be a priority for resolution. In this regard, governments often used the strategy of "divide and rule" by which largescale collective cases were split into a series of small-scale cases. They were then mediated separately in order to disunite workers and defuse potential collective actions (Chen and Xu 2012, 101-102). Therefore, strengthening the mediatory capacity of arbitration institutions resulted in the decrease of massive collective labor disputes, but not the direct decrease of small-scale collective labor disputes. Statistically speaking, arbitral mediation may not directly reduce the proportion of collective cases among all labor disputes. ${ }^{11}$

\section{(B) Robustness test}

The preliminary results above need further testing of robustness in regard to the construction of measured terms and causal inference. For the measured items, since the author constructed both the dependent and explanatory variables, measurement errors may exist in them. In this regard, this article validates the constructed items by replacing the measured terms. The original explanatory variable is obtained by adding up the cases of mediation inside and outside labor arbitral channels, whereas the replacement item of mediation capacity is achieved by dividing cases into extra-arbitral mediation and arbitral mediation, which are respectively calculated by the proportions of cases successfully mediated prior to the filing of cases and in arbitral court. The two dependent variables-scale and frequency of collective disputes-are also replaced by two new indicators: the proportion of employees involved in collective disputes admitted by labor arbitral institutes in the total urban workforce (unit: persons per 10,000 people), and the ratio of collective labor disputes admitted by labor arbitral institutes to the number of total urban workforce (unit: incidents per 10,000 people). Table 6 shows the results with these alternative items. 
Table 5 Province-level panel analysis of the determinants of collective labor disputes, 1999 to 2011

\begin{tabular}{|c|c|c|}
\hline Models & (1) & (2) \\
\hline Dependent variables & $\begin{array}{l}\text { Average involved workers per collective } \\
\text { dispute case accepted by arbitration } \\
\text { institutions (Ln) }\end{array}$ & $\begin{array}{l}\text { Proportion of collective dispute } \\
\text { cases accepted by arbitration } \\
\text { institutions ( } L n)\end{array}$ \\
\hline \multicolumn{3}{|l|}{ Explanatory variables } \\
\hline \multirow{2}{*}{$\begin{array}{l}\text { Mediatory capacity of labor } \\
\text { arbitration institutions }\end{array}$} & $-0.923^{*}$ & -0.066 \\
\hline & $(0.400)$ & $(0.444)$ \\
\hline \multicolumn{3}{|l|}{ Control variables } \\
\hline \multirow{2}{*}{$\begin{array}{l}\text { Appeal rate of labor arbitration } \\
\text { by workers (Ln) }\end{array}$} & $-0.298^{*}$ & $0.315^{*}$ \\
\hline & $(0.134)$ & $(0.119)$ \\
\hline \multirow{2}{*}{$\begin{array}{l}\text { Ratio of social-security disputes } \\
\text { to payment disputes }(\mathrm{Ln})\end{array}$} & 0.076 & $-0.169^{*}$ \\
\hline & $(0.078)$ & $(0.071)$ \\
\hline \multirow{2}{*}{$\begin{array}{l}\text { Expenditures on political and } \\
\text { legal affairs per capita }(L n)\end{array}$} & 0.276 & 0.061 \\
\hline & $(0.295)$ & $(0.391)$ \\
\hline \multirow{2}{*}{$\begin{array}{l}\text { Coverage of enterprise } \\
\text { mediation committees }\end{array}$} & 0.006 & 0.000 \\
\hline & $(0.004)$ & $(0.005)$ \\
\hline \multirow[t]{2}{*}{ GDP per capita (Ln) } & 0.043 & -1.065 \\
\hline & $(0.461)$ & $(0.553)$ \\
\hline \multirow[t]{2}{*}{ FDI dependency } & -3.232 & $11.099^{* *}$ \\
\hline & $(4.150)$ & $(4.082)$ \\
\hline \multirow[t]{2}{*}{ Scale of urban labor } & $0.001^{* *}$ & -0.000 \\
\hline & $(0.000)$ & $(0.000)$ \\
\hline \multirow[t]{2}{*}{ Marketization of labor } & -0.112 & -0.178 \\
\hline & $(1.087)$ & $(1.105)$ \\
\hline \multirow{2}{*}{$\begin{array}{l}\text { Ratio of employees in } \\
\text { secondary industry to those in } \\
\text { tertiary industry }\end{array}$} & -0.455 & -0.324 \\
\hline & $(0.425)$ & $(0.440)$ \\
\hline \multirow[t]{2}{*}{ Unemployment rate } & $0.349^{* *}$ & -0.035 \\
\hline & $(0.114)$ & $(0.136)$ \\
\hline \multirow{2}{*}{$\begin{array}{l}\text { Ratio of resident population to } \\
\text { registered population }\end{array}$} & -2.669 & $3.977^{* *}$ \\
\hline & $(1.434)$ & $(1.515)$ \\
\hline \multirow[t]{2}{*}{ Constants } & 154.539 & 27.471 \\
\hline & $(155.373)$ & $(207.752)$ \\
\hline Province-fixed effects & Yes & Yes \\
\hline Period-fixed effects & Yes & Yes \\
\hline Province-specific time trend & Yes & Yes \\
\hline Observations & 280 & 280 \\
\hline R-squared & 0.500 & 0.722 \\
\hline
\end{tabular}

Huber-White standard errors in parentheses

*:******Denote significance at the 95,99 , and $99.9 \%$ levels, respectively 
Table 6 List of alternative measurements

\begin{tabular}{llllll}
\hline Variables & Obs & Mean & Std & Min & Max \\
\hline Extra-arbitral mediatory capacity of labor arbitration institutions & 325 & 0.24 & 0.16 & 0.00 & 0.80 \\
Arbitral mediatory capacity of labor arbitration institutions & 325 & 0.26 & 0.10 & 0.05 & 0.76 \\
Ratio of involved workers in collective labor disputes to urban labor (Ln) & 402 & 2.38 & 1.03 & -2.09 & 6.12 \\
Ratio of collective labor disputes to urban labor (Ln) & 402 & -0.79 & 0.95 & -3.93 & 3.35 \\
\hline
\end{tabular}

Using alternative items, the estimated results by the LSDV method are highly consistent with earlier preliminary results. In model 3, arbitral and extra-arbitral mediation reduced the average numbers of workers involved in admitted collective disputes (natural logarithm) at $5 \%$ significance level, while in model 4 , the coefficient of alternative explanatory variables toward the proportion of collective disputes is still not significant. With alternative dependent variables, the regression coefficient of the mediation capacity of arbitral institutes toward the proportion of employees involved in collective labor disputes in the urban labor force (natural logarithm) is -1.089 at 0.01 significance level, and not able to pass a significant test toward the ratio of admitted collective disputes to the urban labor force (natural logarithm) (Table 7).

Even taking the correction of measurement error into account, causal inference is still unreliable based on the preliminary results above. Although hypothesis one passes the test with the above analysis, it suffers from the endogeneous problem. That is to say, the reduced-scale of collective disputes may have decreased the difficulty of mediation, which consequently enhanced the proportion of successful mediation. Thus, the statistically negative correlation may also be the result of a reverse causality. To test the robustness of causality, this article takes two measures. First, it substitutes values of explanatory variables with one lag, using time lag to overcome the problem of reciprocal causation. The other measure uses the system-generalized method of moments (System-GMM), using the second lag of explanatory variables as an instrument to adjust the models (discussion of this method can be obtained from Blundell and Bond 1998; Roodman 2009).

Table 8 shows the results of LSDV estimation with one-lagged explanatory variables, and one-step robust and two-step robust System-GMM, respectively. In model 7, the coefficient reduces to -0.777 using an explanatory variable with one lag and does not pass the significance test. This change is likely due to the demonstrative effect: if the arbitral institutions spare no effort to mediate collective disputes and show a strong capacity to deal with those disputes, it could encourage more workers to file collective appeals. Since a time lag existed between the dissemination of information on the successful resolution of labor disputes and the announcement of filing a collective dispute, the demonstration effect would be greater in later time periods. When the models use one-lagged explanatory variables, there is thus an offset between the positive demonstration effect and negative differentiation effect, causing an insignificant decline in the regression coefficient. ${ }^{12}$ In contrast, the results estimated by the system-GMM are consistent with the preliminary findings in the foregoing analysis. In model 9 and model 11, the regression coefficients of the mediation capacity of arbitral institutes toward the scale of collective disputes are -1.298 and -3.636 and significant at the $5 \%$ level. ${ }^{13}$ The test result of AR(2) shows that the differences in the residuals of these two models do not exhibit second-order serial correlation. ${ }^{14}$ The result of the Sargan test 
Table 7 Robustness test of measured items

\begin{tabular}{|c|c|c|c|c|}
\hline Models & (3) & (4) & (5) & (6) \\
\hline $\begin{array}{l}\text { Dependent } \\
\text { variables }\end{array}$ & $\begin{array}{l}\text { Average involved workers } \\
\text { per collective dispute case } \\
\text { accepted by arbitration } \\
\text { institutions (Ln) }\end{array}$ & $\begin{array}{l}\text { The proportion of } \\
\text { collective dispute cases } \\
\text { accepted by arbitration } \\
\text { institutions (Ln) }\end{array}$ & $\begin{array}{l}\text { Ratio of workers } \\
\text { involved in } \\
\text { collective labor } \\
\text { disputes to urban } \\
\text { labor (Ln) }\end{array}$ & $\begin{array}{l}\text { Ratio of } \\
\text { collective } \\
\text { labor disputes } \\
\text { to urban labor } \\
\text { (Ln) }\end{array}$ \\
\hline \multicolumn{5}{|l|}{$\begin{array}{l}\text { Explanatory } \\
\text { variables }\end{array}$} \\
\hline \multirow{2}{*}{$\begin{array}{l}\text { Extra-arbitral } \\
\text { mediatory } \\
\text { capacity of labor } \\
\text { arbitration } \\
\text { institutions }\end{array}$} & $-0.827^{*}$ & -0.033 & & \\
\hline & (0.398) & $(0.439)$ & & \\
\hline \multirow{2}{*}{$\begin{array}{l}\text { Arbitral mediatory } \\
\text { capacity of labor } \\
\text { arbitration } \\
\text { institutions }\end{array}$} & $-1.541^{*}$ & -0.277 & & \\
\hline & $(0.744)$ & $(0.726)$ & & \\
\hline \multirow{2}{*}{$\begin{array}{l}\text { Mediatory } \\
\text { capacity of labor } \\
\text { arbitration } \\
\text { institutions }\end{array}$} & & & $-1.089^{* *}$ & -0.165 \\
\hline & & & $(0.409)$ & $(0.440)$ \\
\hline \multirow[t]{2}{*}{ Constants } & 154.109 & 27.324 & 5.221 & -104.318 \\
\hline & (153.751) & (208.907) & (208.262) & $(213.600)$ \\
\hline $\begin{array}{l}\text { Previous control } \\
\text { variables }\end{array}$ & Yes & Yes & Yes & Yes \\
\hline $\begin{array}{l}\text { Province-fixed } \\
\text { effects }\end{array}$ & Yes & Yes & Yes & Yes \\
\hline $\begin{array}{l}\text { Period-fixed } \\
\text { effects }\end{array}$ & Yes & Yes & Yes & Yes \\
\hline $\begin{array}{l}\text { Province-specific } \\
\text { time trend }\end{array}$ & Yes & Yes & Yes & Yes \\
\hline R-squared & 0.503 & 0.723 & 0.692 & 0.662 \\
\hline Observations & 280 & 280 & 280 & 280 \\
\hline
\end{tabular}

Huber-White standard errors in parentheses

*******Denote significance at the 95,99 , and $99.9 \%$ levels, respectively

also shows that the instrumental variables of both models are exogenous. However, in the corresponding model, the relationship between the mediation capacity of labor arbitral institutes and the frequency of collective incidents still does not pass the significance test. In model 8 , model 10, and model 12, both one-lagged and current explanatory variables do not pass the significance test. In model 10 and model 12, the Sargan test shows that there may be endogenous instrumental variables. After pushing the lag time for three lags, the endogeneity disappears, yet the mediation capacity of arbitral institutes still does not pass the significance test.

\section{Conclusions}

Since the re-establishment of the disposal system of labor disputes in 1986, the Chinese state's capacity to absorb collective struggles of workers has been growing. While the absolute number of collective labor disputes admitted by arbitral institutes increased, the scale and frequency of large-scale collective labor disputes declined. This paper argues 
Table 8 Robustness test of the causality between mediatory capacity of labor arbitration institutions and handled collective labor disputes

\begin{tabular}{|c|c|c|c|c|c|c|}
\hline Models & (7) & (8) & (9) & (10) & (11) & (12) \\
\hline \multirow[t]{2}{*}{ Methods } & LSDV & LSDV & System-GMM & System-GMM & System-GMM & System-GMM \\
\hline & & & One-step & One-step & Two-step & Two-step \\
\hline Dependent variables & $\begin{array}{l}\text { Average involved workers per } \\
\text { collective dispute case } \\
\text { accepted by arbitration } \\
\text { institutions (Ln) }\end{array}$ & $\begin{array}{l}\text { Proportion of collective } \\
\text { dispute cases accepted } \\
\text { by arbitration institutions } \\
\text { (Ln) }\end{array}$ & $\begin{array}{l}\text { Average involved workers per } \\
\text { collective dispute case } \\
\text { accepted by arbitration } \\
\text { institutions (Ln) }\end{array}$ & $\begin{array}{l}\text { Proportion of collective } \\
\text { dispute cases accepted } \\
\text { by arbitration institutions } \\
\text { (Ln) }\end{array}$ & $\begin{array}{l}\text { Average involved workers per } \\
\text { collective dispute case } \\
\text { accepted by arbitration } \\
\text { institutions (Ln) }\end{array}$ & $\begin{array}{l}\text { Proportion of collective } \\
\text { dispute cases accepted } \\
\text { by arbitration institutions } \\
\text { (Ln) }\end{array}$ \\
\hline \multirow{2}{*}{$\begin{array}{l}\text { Dependent variables } \\
\text { (Lag1) }\end{array}$} & & & $0.197^{* *}$ & $0.330^{*}$ & -0.022 & -0.134 \\
\hline & & & $(0.070)$ & $(0.132)$ & $(0.520)$ & $(0.267)$ \\
\hline \multicolumn{7}{|l|}{ Explanatory variables } \\
\hline \multirow{2}{*}{$\begin{array}{l}\text { Mediatory capacity of } \\
\text { labor arbitration } \\
\text { institutions }\end{array}$} & & & $-1.298^{*}$ & 0.986 & $-3.636^{*}$ & 3.201 \\
\hline & & & $(0.587)$ & $(0.722)$ & (1.444) & $(1.700)$ \\
\hline \multirow{2}{*}{$\begin{array}{l}\text { Mediatory capacity of } \\
\text { labor arbitration } \\
\text { institutions (Lag1) }\end{array}$} & -0.777 & -0.073 & & & & \\
\hline & $(0.448)$ & $(0.376)$ & & & & \\
\hline $\begin{array}{l}\text { Previous control } \\
\text { variables }\end{array}$ & Yes & Yes & Yes & Yes & Yes & Yes \\
\hline Province-fixed effects & Yes & Yes & Yes & Yes & Yes & Yes \\
\hline Period-fixed effects & Yes & Yes & Yes & Yes & Yes & Yes \\
\hline $\begin{array}{l}\text { Province-specific time } \\
\text { trend }\end{array}$ & Yes & Yes & Yes & Yes & Yes & Yes \\
\hline AR(1) & & & $-3.20 p=.001$ & $-2.48 p=.013$ & $-0.88 p=.379$ & $-1.04 p=.299$ \\
\hline
\end{tabular}


Table 8 Robustness test of the causality between mediatory capacity of labor arbitration institutions and handled collective labor disputes (Continued)

\begin{tabular}{|c|c|c|c|c|c|c|}
\hline $\operatorname{AR}(2)$ & & & $1.24 p=.213$ & $-0.93 p=.351$ & $0.17 p=.866$ & $-0.62 p=.536$ \\
\hline Sargan test & & & $\mathrm{Chi}^{2}=78.13 p=.110$ & $\mathrm{Chi}^{2}=59.01 p=.043$ & $\mathrm{Chi}^{2}=36.34 p=.636$ & $\mathrm{Chi}^{2}=53.80 p=.028$ \\
\hline Observations & 272 & 272 & 279 & 279 & 279 & 279 \\
\hline R-squared & 0.430 & 0.723 & & & & \\
\hline
\end{tabular}

Huber-White standard errors in parentheses

*******Denote significance at the 95,99 , and $99.9 \%$ levels, respectively 
that the individualization of labor disputes within arbitral channels is related to the state's strengthening capacity to mediate collective labor disputes. In addition to gradually expanding institutionalized channels, a growing number of resources and organizations have been mobilized to mediate collective labor disputes. In the grand mediation era, the mediation strategies of the state are becoming increasingly sophisticated and are starting to classify labor disputes with different kinds of appeals and different kinds of ownership before mediation. These continuously improving and expanding mediation mechanisms produced significant effects of prevention and factorization on workers' labor disputes during China's transition. Through statistical testing of provincial-level panel data from 1999-2011, this article finds that mediation by labor arbitral institutes has significantly reduced the average scale of admitted labor disputes but failed to lower the occurrence of collective disputes. On one hand, this shows that the strategy of mediate first effectively channeled collective actions and broke up the solidarity of workers. On the other hand, it reveals the fact that arbitral mediation is highly selective. This is reflected in the strategy of "focusing on large-scale ones but ignoring small-scale ones" taken by arbitral institutes. They concentrate on the prevention of and intervention in large-scale collective disputes, and neglect those of small scale or by individuals. As a result, arbitral mediation only reduced the number of largescale collective cases and did not directly reduce the number of small-scale cases. Statistically speaking, arbitral mediation resulted in a substantial reduction in the average scale of collective disputes but did not directly reduce the proportion of collective cases among all labor disputes.

These findings are theoretically, conceptually, and empirically significant. Theoretically, they explain why large-scale labor movements did not occur during China's transformation. One existing view states that workers in state-owned enterprises protested according to the ethics of survival. They sought economic interests that would sustain their living rather instead of civil rights. Therefore, their struggles can often be dissolved by temporary compensation policy by the state (Cai 2002; Chen 2000, Lee 1999). However, it is difficult to explain why since the late 1990s the fight of workers in nonstate-owned enterprises was controlled. Another explanation stresses the corporatist strategy of preemptive action by trade unions (Chan 1993), but this does not explain why foreign-funded and private enterprises with weak unions also lacked labor movements. One other view deems that the state actively fulfilled the rights of individual workers during the legislative process, such as regularization of contracts, salary, working conditions, benefits, and so on, but the collective rights of forming organizations, strikes, collective negotiations, and others are not granted to workers (Chen 2007). However, this view cannot explain workers' huge differences in rights protection in terms of methods of struggle and behavior in different areas under a uniform legal framework. After taking these factors into consideration, this work finds that all levels of governments continuously strengthened the various mechanisms of mediation and consolidated their own capacity for mediation, and thus successfully dispersed workers' solidarity and dissolved their collective actions.

Conceptually, existing studies emphasize the arbitrary role of the Chinese authoritarian state (Cai 2008). This work finds that the state has adopted mediation as a flexible channeling strategy that successfully the collective struggle of workers after controlling the factor of heavy-handed repression for maintaining social stability that dominated the committees of politics and law. Empirically, this conclusion does not agree that the 
government can effectively resolve workers' collective struggles by enlarging the scope of mediation. For a long time, the repression to maintain stability that was led by committees of politics and law did not really play a role; therefore, in recent years, governments began to shift their methods of dealing with disputes from blocking to channeling. All levels of governments, from central to local, were keen to promote a variety of grand mediation mechanisms. However, many grassroots-level mediation organizations lacked sufficient professional legal ability to handle the increasingly complicated labor disputes, resulting in very rough and oversimplified grassroots-level mediation and leaving a large number of labor disputes mediated but not resolved. Moreover, this kind of mediation required excessive involvement of all levels of governmental departments in labor disputes. The arbitrary intervention by the state neutralized the equal and institutionalized mechanism of negotiation and consultation between employees and employers inside enterprises. Over time, the state was required to spend a great deal of administrative resources on absorbing a wider range of collective labor struggles. Moreover, the state's stubborn preference of mediation over strict regulation (such as active labor inspections, arbitration awards, the administration of justice, and so on) will in the long run soften the binding power of labor laws and fuel unscrupulous violations by employers. Under the circumstances of irregular grassroots-level mediation, the absence of negotiation mechanisms between employers and employees, excessive political mobilization of administrative resources, and longrange suspension of coercive powers, the rights of workers were not truly protected. Mediation could only help obtain a temporary compromise, rather than play a fundamental role in channeling disputes, which in turn forced the state to mediate selectively according to the scale and intensity of collective disputes-focusing on large ones and ignoring small ones. As a result, although statistically the average scale of collective labor disputes decreased due to the resolution of large-scale collective disputes, in reality, the number of small-scale and individual disputes still remained high. The mass incidents caused by rights-defense activities also appeared to be endless. There have been some signs that Chinese workers have begun to seek solutions outside institutionalized relief channels and are turning to violent approaches. This article thus insists that, in the long run, only by enhancing the capacity to legally handle labor disputes, recognizing the collective rights of workers, and establishing a good mutual consultation mechanism between employers and employees can the state resolve labor disputes without mediation.

\section{Endnotes}

${ }^{1}$ Data source: Yearbook of Chinese Labor Statistics (over years).

${ }^{2}$ Data source: Yearbook of Chinese Labor Statistics (over years).

${ }^{3}$ Source: China Statistical Yearbook of Unions, China Labor Statistical Yearbook, and China Labor Yearbook over years, and Chinese Labor Net: History and Current Situation of the Chinese Settlement System of Labor Disputes (http://www.labournet.com.cn/ldzy/ckzl/ckzl.asp).

${ }^{4}$ Data source: Yearbook of Chinese Labor Department over years.

${ }^{5}$ In order to expand the reach of mediation committees in enterprises, the new law no longer regulated that mediation committees had to be represented by three parties: trade unions, representatives of enterprises, and representatives of workers. Instead, they are composed of only two parties: representatives of workers and representatives of enterprises. In particular, the former has to be elected by all employees or by 
members of trade unions. This adjustment was a response to both the dependency of trade unions on enterprises and the weakness of mediators in real situations. It also reflects the fact that the state wants mediation committees to reach enterprises that were not covered by trade unions.

${ }^{6}$ In order to avoid the situation in which workers took protests outside of the institutionalized relief channels due to the inability of arbitral institutes and the lengthy arbitration proceedings, the Law of Mediation and Arbitration further expanded the scope of admission. In terms of content, the new law also explicitly included disputes on payment for labor, medical expenses related to work injury, economic compensation, and so on in the scope of acceptance. In regard to timeliness, the new law also extended the valid length of time from 60 days to 1 year. These adjustments laid a systematic foundation for more broadly absorbing the actions of workers' struggles.

${ }^{7}$ It should be noted that the admitted collective disputes by arbitral institutes may not reflect the severity of collective labor conflicts in China's transition for the reason that many conflicts occurred before or after arbitration proceedings. Moreover, arbitral mediation could not represent the nationwide capacity of mediation because there was a large number of labor disputes mediated by mediation committees within enterprises, people's mediation committees inside village (neighborhood) committees, the judicial offices at the basic level, social security stations of villages, towns, and streets, and governmental courts at all levels. Subject to the availability of data published by officials, this study can only examine the effect of pre-court mediation, either arbitral or extra-arbitral, on the cases of collective disputes that were formally arbitrated. Even if the impact of these mediation mechanisms passed the test, it only showed that they inhibited collective labor disputes within arbitral and relief channels, but did not reflect that they effectively resolved collective labor disputes during China's transition. However, as mentioned before, the principle of "mediation first" that was implemented throughout the channels of institutionalized relief aimed at preventing workers from taking collective actions while seeking (quasi-)judicial remedies at the same time. The rights protection actions of Chinese people did not take place in an either-or setting between judicial remedies and collective actions; they often had to resort to both collective actions and judicial help in order to catch the attention of governments (O’Brien \& Li 2004).

${ }^{8}$ It should be noted that the main objects of mediation committees in enterprises and arbitral mediation were relatively separated. Respectively, they were labor disputes in state-owned and non-state-owned sectors. As discussed in previous literature and historical analysis, a large difference existed between those two types of disputes in terms of the people involved, attributes, and governments' responses.

${ }^{9}$ The data related to mediation prior to 1999 has too many missing values and thus cannot be analyzed.

${ }^{10}$ Each province may have some properties that did not change over time. Each year may also have some national-level variation (such as the legislation of new labor laws). These characteristics and changes may simultaneously affect the capability of arbitral mediation and the scale and frequency of collective labor disputes. For example, one of the most important effects from one year may be the Law of Labor Dispute Mediation and Arbitration in 2008 that changed the definition of collective labor disputes, increasing the number of workers from "three or more" to "more than ten." This work sets the year variable as a fixed effect to solve this problem, which could affect the estimates in this paper. 
${ }^{11}$ The proportion of collective labor disputes admitted by labor arbitral institutes declined dramatically since 2006, which may be related to the use of grand mediation. New mediators such as people's mediation committees, judicials, and other grassroots organizations of comprehensive management and stability maintenance filtered a portion of collective cases for arbitral institutes. However, there does not currently exist any provincial data on the mediation performance of these organizations, and thus, they could not be included in the model of this work. This limitation needs to be addressed after the release of new data.

${ }^{12}$ The demonstration effect has actually been solved by controlling the occurrence of labor complaints in the analysis of the current period.

${ }^{13}$ Due to the limited sample size, the standard errors of one-step and two-step estimation may be underestimated. This work thus adopts the method of finite-sample estimation to overcome that problem, providing an estimate of the $t$ statistic instead of the commonly used $z$ statistic.

${ }^{14} \mathrm{GMM}$ also requires that residuals are sequentially independent in the second order. This can be verified by the AR test with a null hypothesis that no serial correlation exists.

Competing interests

The authors declare that they have no competing interests.

\section{Acknowledgements}

This work was funded by the Fundamental Research Funds for the Central Universities, the Guangdong Province Philosophy and Social Sciences Youth Project under the 12th Five-Year Plan (GD14YGL08), and two projects of National Social Science Foundation of China (13\&ZD041, and 15CGL052). Thanks to the anonymous reviewers for their pertinent amendments; thanks to Professor Lianjiang Li and Proferssor Feng Chen for their devoted guidance; thanks to Professor Kinglun Ngok for his valuable advice to revise; and thanks to Professor Jun Ma for his support of this study. The author is responsible for all content of this work.

Received: 24 December 2014 Accepted: 9 June 2015

Published online: 29 August 2015

References

Blundell, Richard, and Stephen Bonds. 1998. Initial conditions and moment restrictions in dynamic panel data models. Journal of Econometrics 87(1): 115-143.

Burell, M. 2001. The rule-governed state: China's labor market policy, 1978-1998. In In Faculty of Social Sciences, Department of Government. Sweden: Uppsala University.

Cai, Yongshun. 2002. The resistance of Chinese laid-off workers in the reform period. China Quarterly 170: 327-344.

Cai, Yongshun. 2004. Managed participation in China. Political Science Quarterly 119, no. 3: 425-451.

Cai, Yongshun. 2006. State and laid-off workers in reform China: the silence and collective action of the retrenched. London, New York: Routledge.

Cai, Yongshun. 2008. Local governments and the suppression of popular resistance in China. China Quarterly 193: 24-42.

Central Committee of Comprehensive Management of Social Security. 2010. Opinion on effective performance of comprehensive investigation and mediation of disputes, Apr. 26, 2010.

Central Committee of the Communist Party of China, and State Council.1986. Announcement of seriously implementing several provisions on labor system reform, Apr. 18, 1986.

Chan, Anita. 1993. Revolution or corporatism—-workers and trade-unions in post-Mao China. Australian Journal of Chinese Affairs 29: 31-61.

Chan, C. 2012. Labor, capital and state: labor conflicts in China from a Marxist perspective. Taiwanese Journal of Sociology 50: 165-204.

Chen, Feng. 2000. Subsistence crises, managerial corruption and labour protests in China. China Journal 44: 41-63.

Chen, Feng. 2003. Between the state and labour: the conflict of Chinese trade unions' double identity in market reform. China Quarterly 176: 1006-1028.

Chen, Feng. 2004. Legal mobilization by trade unions: the case of Shanghai. China Journal 52: 27-49.

Chen, Feng. 2007. Individual rights and collective rights: labor's predicament in China. Communist and Post-Communist Studies 40, no. 1: 59-79.

Chen, Feng. 2009. Union power in China source, operation, and constraints. Modern China 35, no. 6: 662-89.

Chen, Feng. 2010. Trade unions and the quadripartite interactions in strike settlement in China. China Quarterly 201: 104-124.

Chen, Feng, and Mengxiao Tang. 2013. Labor conflicts in China: typologies and their implication. Asian Survey 53(3): 559-583.

Chen, Feng, and Xu Xin. 2012. 'Active judiciary': judicial dismantling of workers' collective action in china. The China Journal 67: 87-108.

Chinese Labor Net. 2009. Brief analysis of nationwide labor arbitration from 1986 to 1990. 
Chinese Labor Net. 2011. Statistical analysis of nationwide labor disputes in 2010.

Chinese Labor Net. 2013. Data analysis of nationwide labor disputes in 2012.

Earl, Jennifer. 2003. Tanks, tear gas, and taxes: toward a theory of movement repression. Sociological Theory 21(1): 44-68.

Earl, Jennifer. 2006. Introduction: repression and the social control of protest. Mobilization 11, no. 2: 129-143.

Editorial Department of Chinese human resources and social security. 2010. Yearbook of Chinese human resources and social security in 2009 (working book). Beijing: Chinese Press of human resources and social security.

Editorial department of Chinese Yearbook of Labor. 1990. Chinese yearbook of labor (1988-1989). Beijing: Chinese Labor Press.

Editorial department of Chinese Yearbook of Labor. 1995. Chinese yearbook of labor (1992-1994). Beijing: Chinese Labor Press.

Editorial department of Chinese Yearbook of Labor. 1997. Chinese yearbook of labor (1995-1996). Beijing: Chinese Labor Press.

Editorial department of Chinese Yearbook of Labor. 1998. Chinese yearbook of labor (1997). Beijing: Chinese Labor Press.

Editorial department of Chinese Yearbook of Labor. 2007. Chinese yearbook of labor (2006). Beijing: Chinese Labor Press.

Gallagher, ME. 2006. Mobilizing the law in China: 'informed disenchantment' and the development of legal consciousness. Law \& Society Review 40, no. 4: 783-816.

Howell, Jude. 2006. Reflections on the Chinese state. Development and Change 37(2): 273-297.

Lee, Ching Kwan. 1999. From organized dependence to disorganized despotism: changing labour regimes in Chinese factories. China Quarterly 157: 44-71.

Lee, CK. 2007. Against the law: labor protests in China's rustbelt and sunbelt. Berkeley: University of California Press.

$L i, F$. "Constructing harmonious labor relationships - a nationwide survey of labor disputes admitted by courts." People's Court Daily, Apr. 22, 2008. http://www.bokee.net/bloggermodule/blog_viewblog.do?id=1911551.

Ministry of human resources and social security of China. 2008. Notice of issuing the propaganda outline of "the mediation and arbitration law of labor disputes of China," no. 7.

Ministry of human resources and social security of China. 2012a. Convention of the starting of a research project on the mediation and coordination mechanism of significant collective labor disputes.

Ministry of human resources and social security of China. 2012b. Annual statistical bulletin of the ministry of human resources and social security of China for 2011.

Ngok, Kinglun. 2008. The changes of Chinese labor policy and labor legislation in the context of market transition. International Labor and Working-Class History 73(1): 45-64.

O'Brien, JK, and Lianjiang Li. 2004. Suing the local state: administrative litigation in rural China. China Journal 51: 75-96.

Oberschall, Anthony. 1973. Social conflict and social movements. Englewood Cliffs, NJ: Prentice Hall.

Peerenboom, Randall. 2009. More Law, less courts: legalized governance, judicialization, and dejudicailization in China In Administrative law and governance in Asia, ed. T Ginsburg and AHY Chen. New York: Routledge.

Policy research department of the All-China Federation of Trade Unions. 1994. Yearbook of Chinese labor unions statistics. Beijing: Chinese Statistics Press.

Roodman, David. 2009. How to do xtabond2: an introduction to difference and system GMM in stata. Stata Journal 9(1): 86-136.

Tian, C. 2008. "Implementing the "Labor Dispute Mediation and Arbitration Law" to promote harmonious and stable labor relations." Available at www.mohrss.gov.cn.

Tilly, Charles. 1978. From mobilization to revolution. Reading, MA: Addison-Wesley Pub. Co.

Walder, Andrew G. 1986. Communist neo-traditionalism: work and authority in Chinese industry. Berkeley: University of California Press.

Wang, Shaoguang. 2006. Regulating death at coal mines: changing mode of governance in China. Journal of Contemporary China 15(46): 1-30.

Wank, DL. 1998. Political sociology contemporary China: state-society images in American China studies. Journal of Contemporary China 7, no. 18: 205-227.

\section{Submit your manuscript to a SpringerOpen ${ }^{\circ}$ journal and benefit from:}

- Convenient online submission

- Rigorous peer review

- Immediate publication on acceptance

- Open access: articles freely available online

- High visibility within the field

Retaining the copyright to your article 